\title{
Atlantic Forest replacement by non-native tree plantations: Comparing aboveground necromass between native forest and pine plantation ecosystems
}

\author{
Silvia Clarisa Zaninovich ${ }^{\mathrm{a}, *}$, José Luis Fontana ${ }^{\mathrm{b}}$, M. Genoveva Gatti ${ }^{\mathrm{a}, \mathrm{c}}$ \\ a Instituto de Biología Subtropical, Universidad Nacional de Misiones, CONICET, Bertoni 85, 3370 Puerto Iguazú, Misiones, Argentina \\ ${ }^{\mathrm{b}}$ Facultad de Ciencias Exactas y Naturales y Agrimensura, Universidad Nacional del Nordeste, Av. Libertad 5400, 3400 Corrientes, Argentina \\ ${ }^{\mathrm{c}}$ Facultad de Ciencias Forestales, Universidad Nacional de Misiones, Bertoni 124, 3380 Eldorado, Misiones, Argentina
}

\section{A R T I C L E I N F O}

\section{Article history:}

Received 30 September 2015

Received in revised form 15 December 2015

Accepted 17 December 2015

Available online 24 December 2015

\section{Keywords:}

Coarse woody debris

Litter layer

Pinus taeda

Water content

\begin{abstract}
A B S T R A C T
Necromass is a critical structural and functional component of forest ecosystems that represents an important and relatively long-lived aboveground forest carbon pool. In the Atlantic Forest of Northern Argentina, a large area of native forest has been replaced by commercial, non-native tree plantations. We hypothesized that total aboveground necromass would be affected by forest conversion. Specifically, we expected a general decrease in necromass with conversion to non-native pine plantations. In five different Pinus taeda plantations (PP) and five native forests (NF) sites in Misiones, Argentina, we quantified the fallen coarse woody debris (CWD: $>2 \mathrm{~cm}$ diameter) and litter layer (LL: $<2 \mathrm{~cm}$ diameter) biomass. We compared NF and PP ecosystems with respect to biomass, CWD size classes, decomposition levels, mass moisture content and water volume retained. Coarse woody debris was greatly reduced in PP $\left(1.7 \pm 0.5 \mathrm{Mg} \mathrm{ha}^{-1}\right)$ compared to NF $\left(7.5 \pm 3.5 \mathrm{Mg} \mathrm{ha}^{-1}\right)$. However, LL biomass in pine plantations increased by $180 \%$, such that similar amounts of total fallen necromass (CWD $+\mathrm{LL}$ ) were observed in NF $\left(13.5 \pm 1.1 \mathrm{Mg} \mathrm{ha}^{-1}\right)$ and PP $\left(14.1 \pm 3 \mathrm{Mg} \mathrm{ha}^{-1}\right)$. The CWD size class with the highest biomass was $\mathrm{CWD}>10 \mathrm{~cm}$ in NF $\left(5.4 \pm 3.7 \mathrm{Mg} \mathrm{ha}^{-1}\right)$, and $2-5 \mathrm{~cm}$ in PP $\left(1 \pm 0.2 \mathrm{Mg} \mathrm{ha}^{-1}\right)$. Coarse woody debris in NF was principally composed of detritus in intermediate to advanced states of decomposition ( $5.1 \pm 3 \mathrm{Mg} \mathrm{ha}^{-1} ; 68 \%$ of total CWD), while in PP recently dead material accounted for the majority of CWD $\left(0.8 \pm 0.5 \mathrm{Mg} \mathrm{ha}^{-1} ; 49 \%\right.$ of total CWD). Necromass moisture content was similar in both forest ecosystems, and increased as the level of decomposition increased. However, because CWD was more abundant in NF, the water volume retained in NF was four times higher than in PP $(6.38 \pm 1.3$ vs. $1.68 \pm 0.5 \mathrm{~m}^{3} \mathrm{ha}^{-1}$, respectively). The observed differences in necromass can be explained by the stand characteristics of PP, which are monospecific young systems of short harvest cycles and low quality litter where all aboveground biomass is removed during harvesting. Our findings suggest that NF replacement by PP could have large effects on ecosystem function due to changes in the amount and composition of necromass. Specifically, the predominance of fine detritus in PP likely lowers the residence time of carbon and water storage in detritus, as well as ecosystem biodiversity, while also increasing the risk of natural fires. Management strategies that would increase coarse necromass, such as not removing harvest residues and extending tree harvest age, should be considered.
\end{abstract}

(c) 2015 Elsevier B.V. All rights reserved.

\section{Introduction}

An important feature of native forests is that they possess high quantities of dead material in all stages of decay, as well as high proportions of old, live trees with dead components (Harmon et al., 1986). As this necromass decomposes relatively slowly, it

\footnotetext{
* Corresponding author.

E-mail address: sczaninovich@gmail.com (S.C. Zaninovich).
}

represents an important long-lived aboveground forest carbon (C) pool (Liu et al., 2006) that plays an important role in biogeochemical cycles (Krankina and Harmon, 1995; Zhou et al., 2014) and links the above and belowground biota (Bardgett and Wardle, 2010). Necromass is also a critical structural and functional component of forest ecosystems (Franklin et al., 1987). It provides habitat for a large variety of organisms (Sefidi and Marvie Mohadjer, 2010) and it is a key component for both tree regeneration and the maintenance of environmental heterogeneity 
and biological diversity (Harmon et al., 1986; Stevens, 1997). Moreover, in tree plantations, accumulated aboveground debris is an important source of nutrients and organic matter that has a strong impact on nutrient cycling, especially in short-rotation forest plantations (Tiarks et al., 1998). Previous studies have suggested that necromass regulates hydrologic processes (Lindenmayer and Noss, 2006) and influences the probability of wildfires (Uhl and Kauffman, 1990). However, the effect of forest management and the replacement of native forests with tree plantations on necromass stocks, and the dynamics of these stocks in forest ecosystems, is still poorly understood.

Aboveground necromass stocks consist of litter layer (LL) that includes all necromass with a diameter less than $2 \mathrm{~cm}$ (forest floor, fine debris or $\mathrm{O}$ horizon), and coarse woody debris (CWD), the fallen plant detritus larger than $2 \mathrm{~cm}$ (Palace et al., 2012; Binkley and Fisher, 2013). In tropical and temperate forests, the dead organic material typically comprises a substantial proportion of the total aboveground C stocks, accounting for $14-40 \%$ of carbon storage (USDA, 2004; Rice et al., 2004; Palace et al., 2007; Iwashita et al., 2013).

Studies concerning the role of necromass, its characteristics, quantity and quality have increased in recent years, in part because climate change can alter ecosystem $\mathrm{C}$ balance through changes in the dynamics of this pool (Chambers et al., 2000; Woodall and Liknes, 2008; Weedon et al., 2009). In the Amazonian Forest, dry periods have reportedly increased the tree mortality rate (Phillips et al., 2009) producing a pulse of CWD into the necromass pool that raises the carbon storage in this stock (Rice et al., 2004). In tropical montane wet forests, both the CWD decomposition rate and the CWD production rate increase with the mean annual temperature, though the increase in decomposition rate is faster, resulting in net $\mathrm{CO}_{2}$ emissions from CWD to the atmosphere with warming (Iwashita et al., 2013). Consequently, necromass stocks could become a carbon source or a carbon sink depending on several variables that change in space and time. Knowledge of these patterns is needed to improve carbon storage and stability in ecosystems (Chambers et al., 2000; Rice et al., 2004; Radtke et al., 2009).

Most of the studies on this subject have been performed in the tropics (Melillo et al., 1993; Potter et al., 1993; Grace et al., 1995; Malhi et al., 1998; Phillips et al., 1998; Martius et al., 2004), while studies in the subtropical forests of Neotropical regions, many of which have been subject to forest replacement in recent decades (Eclesia et al., 2012), are lacking. The Atlantic Forest is one of the most diverse forests of the world, but also among the most threatened. Approximately $84-93 \%$ of its original area has been lost and the remnants are highly fragmented (Ribeiro et al., 2009). In Misiones Province, Argentina, only $40 \%$ of native forest cover remains, and this fraction represents one of the larger portions of continuous Atlantic Forest in the region (Ribeiro et al., 2009). Forest fragmentation and loss in this area have been caused by the conversion of forest to crop and cattle fields and extensive non-native tree plantations for fiber production (Eclesia, 2004; Izquierdo et al., 2008; Ribeiro et al., 2009). Ecological modeling has recently shown that changes in land use and forest fragmentation have greatly decreased carbon storage in aboveground live biomass (Pütz et al., 2014). However, little is known about the effects of changes in land use on necromass stocks.

Tree plantations in tropical and subtropical ecosystems accumulate a significant amount of $\mathrm{C}$ in their aboveground biomass in a short period of time (Hoen and Solberg, 1994; Harmon and Sexton, 1995). Thus, afforestations and the use of forestry products for bioenergy have been proposed as a clean development mechanism to reduce greenhouse gas emissions (UNFCCC, 1992). However, more recent studies have found that afforestation decreases soil organic carbon by $\sim 20 \%$ in plantations under 40 years old (Guo and Gifford, 2002; Eclesia et al., 2012). In South
America the total area planted with different species of the Pinus genus exceeded 4,250,000 ha in 2009 (Simberloff et al., 2010). In Argentina, the afforested area grew rapidly during the last 30 years, today accounting for $1,024,277$ ha with many sites already undergoing their second or third rotation after the native forest replacement. Fast growing plantations in this country are monospecific, and afforestation usually uses the non-native genus Pinus. These plantations occupy $64 \%$ of the total afforested area in the country. In Misiones Province (northeastern Argentina, Atlantic Forest biome), Pinus plantations occupy $10 \%$ of the provincial area, accounting for 306,592 ha (MAGyP, 2015). The most common species is Pinus taeda. In this region, the pine plantations effect on carbon and nutrient cycling has been associated with the harvest system. Soil loss and nutrient instability are moderate with the conventional practice of harvesting only the trunk (the remains of branches, leaves and fruits are left decomposing on the ground; Martiarena, 2008), but they are increased substantially with the system that harvests the whole tree (Goya et al., 2003). Despite the importance of necromass for the nutrient cycling within these productive systems (Tiarks et al., 1998), few studies have analyzed this issue and none have focused on the Atlantic Forest (Ranius and Kindvall, 2004; Radtke et al., 2009).

In this context, we developed the present study with the main objective of quantifying the effects of native forest replacement with non-native P. taeda plantations on necromass stocks. We formulated the following questions: (1) Does the total necromass volume change when non-native tree plantations replace native forest? and (2) Are the different necromass categories equally affected in the pine plantation systems? We hypothesized that necromass would be affected by native forest replacement with $P$. taeda plantations. We expected to find that total necromass, and in particular CWD, would decrease in commercial non-native tree plantations when compared to native forests. To test this hypothesis we quantified and characterized necromass stocks, diameter size classes, decomposition levels and water content in native forests and non-native $P$. taeda plantations in the Semideciduous Atlantic Forest of North eastern Argentina.

\section{Materials and methods}

\subsection{Study site}

This study was carried out over a one-year period (2013-2014), in a private, protected forest area, adjacent to the Iguazú National Park, Misiones province, Argentina $\left(25^{\circ} 48^{\prime} 56.25^{\prime \prime} \mathrm{S}, 54^{\circ} 32^{\prime} 17.28^{\prime \prime} \mathrm{W}\right.$, Fig. 1). The region has a subtropical humid climate with no dry season. The mean annual rainfall is $2000 \mathrm{~mm}$ and the mean annual temperature is $20^{\circ} \mathrm{C}$; the relief is rolling and soils are mostly ultisols derived from basaltic rocks and contain high concentrations of Fe, Al and Si (Ligier et al., 1990). During the sampling period the mean monthly precipitation was $182 \mathrm{~mm}$ and ranged from $74 \mathrm{~mm}$ to $514 \mathrm{~mm}$ (annual total: $2187 \mathrm{~mm}$; TRMM, 2014) and the mean annual temperature was $21^{\circ} \mathrm{C}$ with a minimum of $15^{\circ} \mathrm{C}$ (winter) and a maximum of $25^{\circ} \mathrm{C}$ (summer) (MODIS, 2014).

The Semideciduous Atlantic Forest in Misiones constitutes the southern portion of the Atlantic Forest, which extends along the coast of Brazil up to Paraguay and Argentina, but it is also included within a broad group of neotropical seasonally dry forests (Prado and Gibbs, 1993). The tree structure is uneven-aged and includes more than 70 tree species (Chediack, 2008) usually covered with lianas and epiphytes, mixed with shrubs, bamboos and grasses (Parodi, 1964). At the study sites, tree density is 1200 ind/ha, the basal area of trees larger than $10 \mathrm{~cm}$ DBH (diameter at breast height) is $28.74 \mathrm{~m}^{2} \mathrm{ha}^{-1}$ and the tree canopy height is about $30 \mathrm{~m}$ (Chediack, 2008). The canopy vegetation is dominated by 


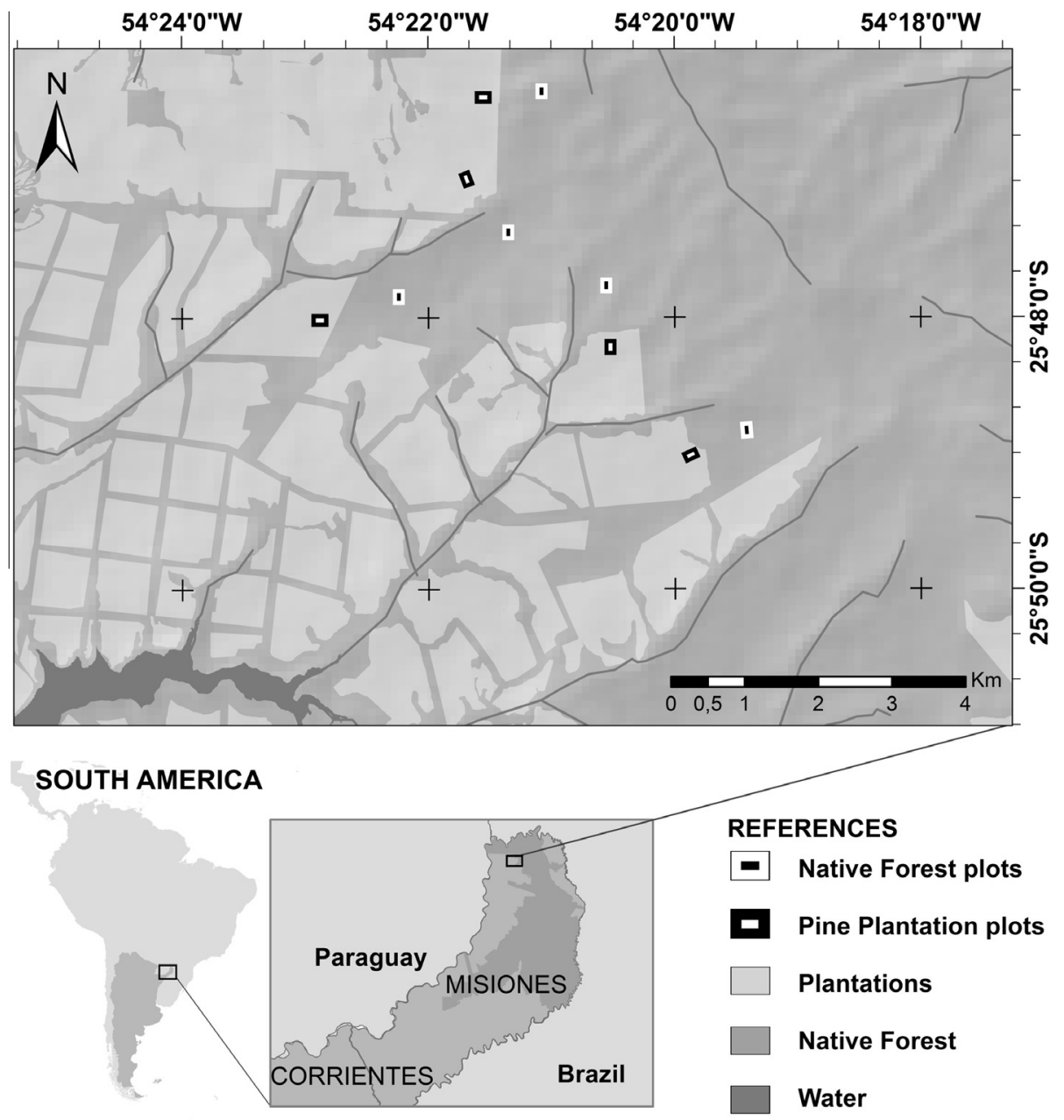

Fig. 1. Study area in Northern Misiones Province (Argentina). Experimental plots in pine plantations and native forest are shown.

trees species such as Nectandra megapotamica (Spreng.) Mez (Lauraceae), Cedrela fissilis Vell. (Meliaceae), Balfourodendron riedelianum (Engl.) Engl. (Rutaceae), Chrysophyllum gonocarpum (Mart. \& Eichler) Engl. (Sapotaceae), Cordia trichotoma (Vell.) Arráb. Ex Steud. (Boraginaceae), Cordia americana L. (Boraginaceae), Bastardiopsis densiflora (Hook. and Arn.) Hassler (Malvaceae), and Lonchocarpus leucanthus Burkart (Fabaceae). The most common subdominant tree species are Sorocea bonplandii (Baill.) W.C. Burger, Lanj. \& Wess. Boer (Moraceae), Trichilia catigua Adr. Juss. and Trichilia elegans A. Juss. (Srur et al., 2009). Two palm species, Euterpe edulis Mart. (Arecaceae) and Syagrus romanzoffiana (Cham.) Glassman are also frequent in this forest (Gatti et al., 2008). In sites with an open canopy the understory is dominated by bamboo species, mainly of the genus Chusquea (Montti et al., 2011).

The non-native $P$. taeda plantations in the study area are intended to be used for the cellulose-paper industry. This is an intensive forest plantation ecosystem with no pruning or thinning and a harvest age of 9-14 years. Trees at the studied plots were 9 years old at the beginning of the study and were harvested by the company at the end of the study, when they were 10 years old. The average canopy height was $15 \mathrm{~m}$ and there were $1703 \mathrm{ind} / \mathrm{ha}$, with a basal area of approximately $50 \mathrm{~m}^{2} /$ ha. The understory was mainly composed of ferns and tree seedlings.

\subsection{Experimental design and field sampling methods}

We performed field inventories in adjacent stands of native forest and non-native tree plantations (located at 290-350 m.a.s.l.,
Fig. 1). We established 10 plots of $100 \times 40 \mathrm{~m}$ : five plots in five independent $P$. taeda plantations (PP), and five adjacent plots in continuous native forest (NF). Every plot in NF was located $700 \mathrm{~m}$ from the PP plot and was separated from the next site by at least $1 \mathrm{~km}$. Within each plot we quantified the aboveground fallen necromass twice a year, once at winter (June-August 2013) and once in summer (December 2013-March 2014).

Types of debris were examined and classified according to the criteria outlined by Keller et al. (2004), Phillips and Baker (2002) and Palace et al. (2012). Litter layer (LL) was comprised of leaf litter, flowers, fruits and fine woody fractions with diameters smaller than $2 \mathrm{~cm}$. Coarse woody debris (CWD) comprised all branches and fallen logs with diameters bigger than $2 \mathrm{~cm}$. This material was classified according to the diameter size into: (1) large: $>10 \mathrm{~cm}$; (2) medium: $5-10 \mathrm{~cm}$ and (3) small: $2-5 \mathrm{~cm}$. Standing dead trees were not measured and their biomass was not considered in the necromass quantification.

The LL was quantified by placing a $0.25 \mathrm{~m}^{2}$ wire square in three points per plot separated by $50 \mathrm{~m}$; all dead fine material within this area was collected and brought to the laboratory. All the material was dried at $65^{\circ} \mathrm{C}$ to constant mass and weighed. Coarse woody debris was sampled inside each plot in three random selected parallel transects of $1 \times 10 \mathrm{~m}$, separated at least by $50 \mathrm{~m}$, during winter and summer. The sites already sampled during winter were not included in summer sampling. All the pieces with diameter $>2 \mathrm{~cm}$ within the transects were sampled and classified according the size classes listed above, and into five decomposition levels. The levels $1-5$, sorted from most recently fallen to most 
decomposed necromass, were defined according to the following criteria: Level 1: newly fallen material with solid and firm wood, intact bark and some leaves and/or fine twigs still attached; Level 2: still solid and firm wood and intact bark but no fine twigs or leaves attached; Level 3: still firm wood but rotten or sloughing bark; Level 4: rotten debris and soft wood, without most of the bark; Level 5: very rotten material and very soft wood (Keller et al., 2004; Phillips and Baker, 2002; Palace et al., 2012). There were thus 15 potential categories which were weighed separately (3 diameter size classes $\times 5$ decomposition levels). Each category was weighed in situ and a subsample of at least $10 \%$ of the material was carried to the laboratory, dried at $65{ }^{\circ} \mathrm{C}$ to constant mass, and weighed. The relation between dry and humid mass in samples was used to estimate total necromass in the field. In case of large fallen trees, length and diameter of the stems within the transect were measured and transversal sections of about $10 \mathrm{~cm}$ thickness were collected and analyzed in the laboratory. We calculated the fresh volume of every cross-sectional disk and, subsequently, dried them in order to estimate the dry weight of every fallen tree sampled in the field.

In order to estimate the necromass dry weight per area $\left(\mathrm{Mg} \mathrm{ha}^{-1}\right)$ we obtained the total weight of the debris in each transect by plot and extrapolated it to hectares.

We also estimated the mass moisture content (\%) in CWD and the water volume $\left(\mathrm{m}^{3} \mathrm{ha}^{-1}\right)$ in the field contained in CWD as following:

Mass moisture content (MC, \%)

$$
=(\mathrm{WW}-\mathrm{DM}) * 100) / \mathrm{DM}
$$

Water volume $\left(\mathrm{WV}, \mathrm{m}^{3} \mathrm{ha}^{-1}\right)=(\mathrm{WW}-\mathrm{DM}) /$ ha

where WW is wet weight and DM is dry mass.

For MC and WV estimation, only data from the winter sampling period were considered. Precipitation was abundant during the summer, making the data invalid for the calculation of this variable.

\subsection{Statistical analyses}

To evaluate the effects of native forest replacement by non-native pine plantations on necromass, three variables were analyzed: dry mass $\left(\mathrm{Mg} \mathrm{ha}^{-1}\right)$, water volume $\left(\mathrm{m}^{3} \mathrm{ha}^{-1}\right)$ and mass moisture content (\%). The factors analyzed were the type of ecosystem (NF and PP), type of debris (CWD, LL), diameter size $(<2 \mathrm{~cm} ; 2-5 \mathrm{~cm} ; 5-10 \mathrm{~cm} ;>10 \mathrm{~cm})$ and decomposition level $(1,2$, $3,4,5)$. To test the differences between groups we performed nonparametric Kruskal-Wallis tests (analysis of variance by rank, one and two ways), because the variances were not equally distributed (Zar, 1999). Post-hoc comparisons between the mean ranks were performed.

\section{Results}

\subsection{Total necromass}

We obtained a total necromass $(\mathrm{TN}=\mathrm{CWD}+\mathrm{LL})$ of $14.1 \pm 3.0$ (mean \pm SE) and $13.5 \pm 1.1 \mathrm{Mg} \mathrm{ha}^{-1}$ in the Native Forest (NF) and non native Pine Plantations (PP) respectively (Fig. 2a). Contrary to what we expected, no differences in total necromass were observed between NF and PP ecosystems (Kruskal-Wallis (KW)one way, $H=0.88, N=5, p=0.421$ ). However, necromass composition varied widely between NF and PP (KW-two ways, $H=13.93$, $N=5, p=0.003$; Fig. 2b). In the NF, litter layer (LL) and coarse woody debris (CWD) were equally represented, $47 \%$ and $53 \%$, respectively ( $\mathrm{KW}$-one way, $H=1.84, N=5, p=0.222$ ). In contrast, in PP, the total necromass was primarily determined by LL, which accounted for $88 \%$ of the total, whereas CWD represented the remaining $12 \%$ (KW-one way, $H=6.82, N=5, p=0.008$; Fig. $2 \mathrm{~b}$ ).

\subsection{Coarse woody debris}

\subsubsection{Size categories}

The CWD was composed of necromass of various sizes in both ecosystems, and the quantity of necromass distributed across the different size categories was different in the PP and the NF (KWtwo ways, $H=14.04, N=5, p=0.015$; Fig. $3 a$ ). The input of CWD $>10 \mathrm{~cm}$ was the most represented in NF, accounting for $72 \%$ of the total CWD $\left(5.4 \pm 3.7 \mathrm{Mg} \mathrm{ha}^{-1}\right)$. Conversely, in the PP ecosystem, the diameter class with the greatest accumulation was $2-5 \mathrm{~cm}$, which accounted for $57 \%\left(1.0 \pm 0.2 \mathrm{Mg} \mathrm{ha}^{-1}\right)$ and the category $>10 \mathrm{~cm}$ represented $36 \%$ of the total CWD (Fig. 3a).

\subsubsection{Decomposition levels}

The quantity of coarse necromass in different levels of decomposition also changed depending on the ecosystem (KW-two ways, $H=32.47, N=5, p<0.001$; Fig. 3b). In NF the most represented decomposition level was level 3 (intermediate stay of decay), comprising $68 \%$ of the total CWD necromass $\left(5.1 \pm 3 \mathrm{Mg} \mathrm{ha}^{-1}\right.$ ), followed by levels 4 and 5 (more decomposed necromass). These three levels constituted nearly all of the CWD necromass (94\%) in forests. In contrast, in PP ecosystems the most represented level was level 1 (recently dead material) making up 49\% of CWD necromass $\left(0.8 \pm 0.5 \mathrm{Mg} \mathrm{ha}^{-1}\right)$, followed by level 3, which accounted for $27 \%$ (0.5 $\mathrm{Mg} \mathrm{ha}^{-1}$ ) (Fig. 3b).

\subsubsection{Moisture content and water volume retained}

The moisture content of CWD was similar in both ecosystems (KW-one way, $H=1.84, \mathrm{df}=1, N=5, p=0.222$ ). The NF had an average water content of $137 \pm 9 \%$ and PP $101 \pm 25 \%$. However, as CWD was much more abundant in NF, the water volume per area retained in coarse necromass was higher in NF than in PP ecosystems, accounting for 6.38 and $1.68 \mathrm{~m}^{3}$ /ha respectively (KW-one way, $H=6.82, N=5, p=0.008$ ) (Table 1 ). The moisture content in coarse necromass increased as the decomposition level increased in both ecosystems, and similar values were obtained for NF and PP within each level (KW-two way, $H=34.28, N=5, p<0.001$; Fig. 4). In NF, a $95 \%$ of the total water volume was retained in CWD decomposition levels 3, 4 and 5 (which together represented 90\% of CWD total dry mass). In PP ecosystems, the percentage of water volume contained in these decomposition levels was 69\% and these necromass categories represented only $34 \%$ of CWD total dry mass (Table 1 ).

\section{Discussion}

Necromass is a key component of the carbon cycle and ecosystem functioning (Krankina and Harmon, 1995; Zhou et al., 2014). We found that NF replacement by PP strongly affect this carbon pool. As expected, the conversion of the Atlantic Forest to nonnative $P$. taeda plantations was associated with an $80 \%$ decrease in CWD. Furthermore, a large increase in litter layer stock was observed in PP, which was nearly double that of the NF. The distinctly unexpected net result was that the total fallen necromass pool (CWD + LL) did not change between NF and PP ecosystems.

The replacement of CWD by LL in PP could have an important impact on ecosystem function and on carbon stability and storage (Chambers et al., 2000; Martius et al., 2004; Woodall and Liknes, 2008; Iwashita et al., 2013; Zhou et al., 2014). Coarse woody debris is a long-lived forest carbon pool, while the litter layer is comparatively short-lived (Woodall and Liknes, 2008; Palace et al., 2008). 


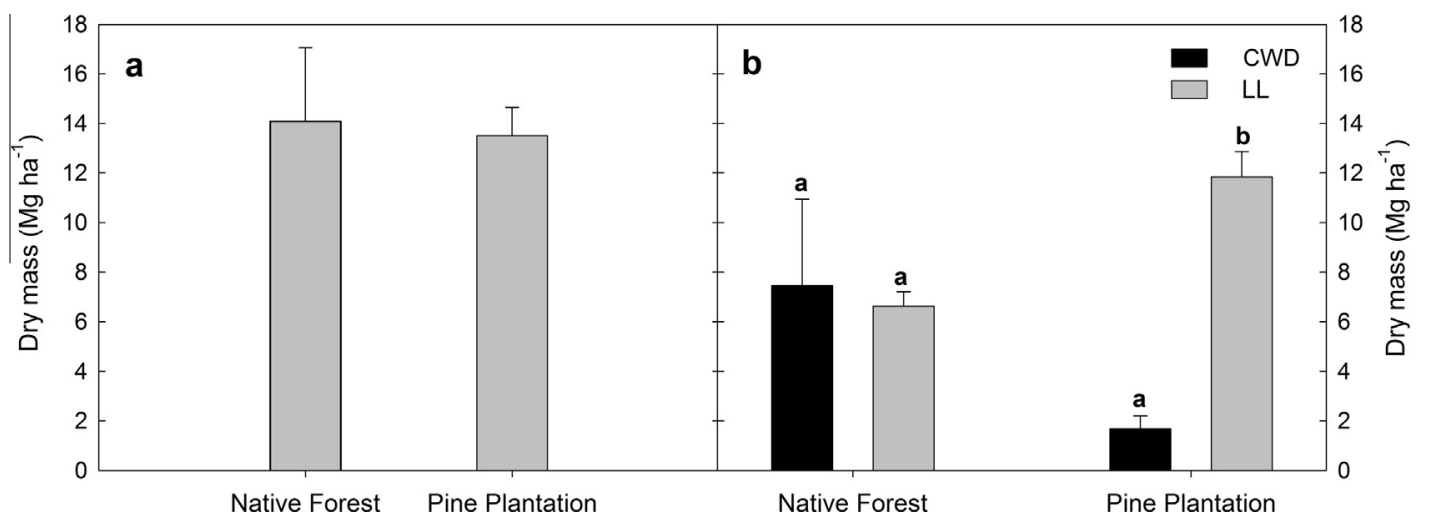

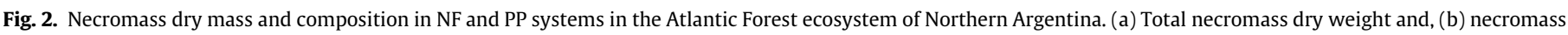
composition in terms of CWD and LL. Different letters indicate significant differences between types of debris within ecosystems.

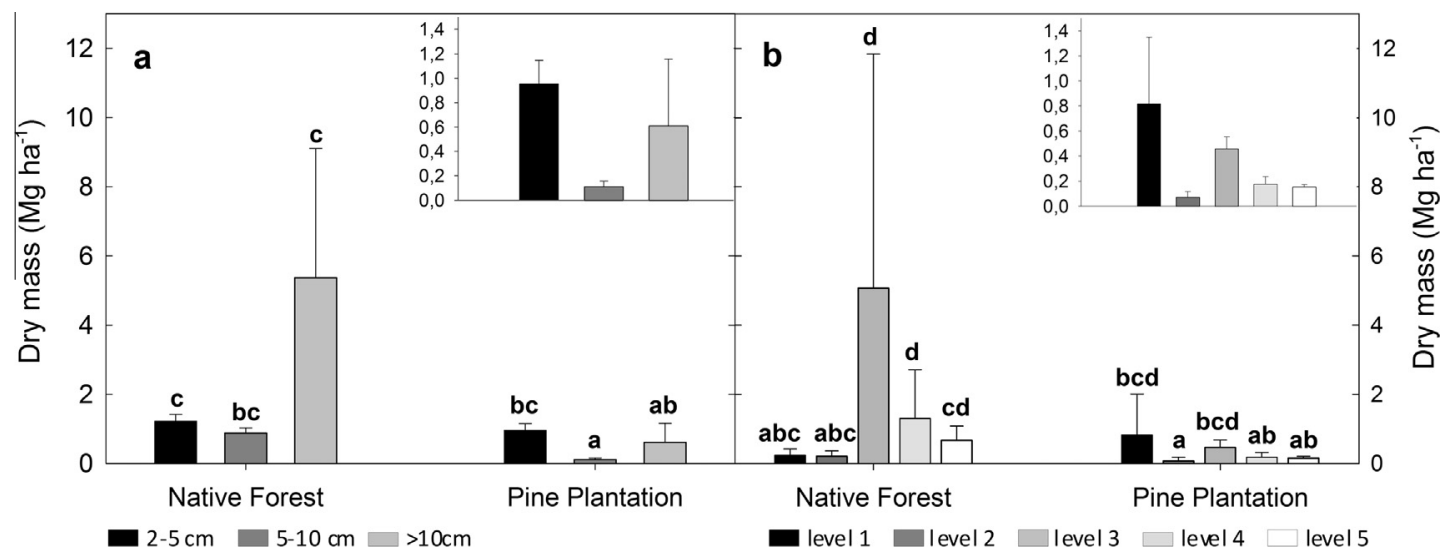

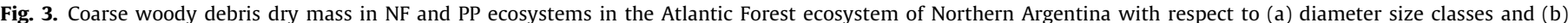

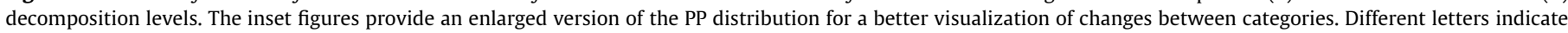
significant differences between CWD and ecosystems.

Table 1

Dry mass and water volume (mean \pm standard error) of CWD with different decomposition levels in NF and PP. Different letters indicate significant differences between sites and levels $(p<0.05)$. KW-two way tests are detailed below. Data correspond to winter necromass measurements (see material and methods for further information).

\begin{tabular}{|c|c|c|c|c|}
\hline \multirow{2}{*}{$\begin{array}{l}\text { Variable } \\
\text { Site }\end{array}$} & \multicolumn{2}{|c|}{ Dry mass $\pm \mathrm{SE}\left(\mathrm{Mg} \mathrm{ha}^{-1}\right)$} & \multicolumn{2}{|c|}{ Water volume $\pm \mathrm{SE}\left(\mathrm{m}^{3} \mathrm{ha}^{-1}\right)$} \\
\hline & NF & $\mathrm{PP}$ & NF & PP \\
\hline $\bar{X}$ total & $4.69 \pm 0.84$ & $2.15 \pm 0.96$ & $6.38 \pm 1.26$ & $1.68 \pm 0.54$ \\
\hline \multicolumn{5}{|c|}{ Decomposition levels } \\
\hline 1 & $0.33 \pm 0.15^{\mathrm{ab}}$ & $1.36 \pm 1.09^{\mathrm{ab}}$ & $0.19 \pm 0.16^{\mathrm{a}}$ & $0.43 \pm 0.32^{a}$ \\
\hline 2 & $0.11 \pm 0.07^{\mathrm{a}}$ & $0.06 \pm 0.04^{\mathrm{a}}$ & $0.09 \pm 0.07^{\mathrm{a}}$ & $0.07 \pm 0.06^{\mathrm{a}}$ \\
\hline 3 & $2.95 \pm 0.77^{c}$ & $0.41 \pm 0.14^{\mathrm{ab}}$ & $2.88 \pm 1.21^{\mathrm{d}}$ & $0.39 \pm 0.16^{\mathrm{abc}}$ \\
\hline 4 & $0.61 \pm 0.03^{b c}$ & $0.17 \pm 0.08^{\mathrm{a}}$ & $1.39 \pm 0.38^{\mathrm{bcd}}$ & $0.37 \pm 0.28^{\mathrm{ab}}$ \\
\hline 5 & $0.68 \pm 0.20^{\mathrm{bc}}$ & $0.15 \pm 0.03^{\mathrm{a}}$ & $1.83 \pm 0.51^{\mathrm{cd}}$ & $0.41 \pm 0.14^{\mathrm{abcc}}$ \\
\hline $\begin{array}{l}\text { KW-two way } \\
\text { test }\end{array}$ & \multicolumn{2}{|c|}{$H=28.2, N=5, p<0.001$} & \multicolumn{2}{|c|}{$H=29.60, N=5, p<0.001$} \\
\hline
\end{tabular}

As a consequence, the increase of the litter layer from $50 \%$ of the total necromass in NF to almost $90 \%$ in PP decreases the average residence time of the carbon in the necromass pool in PP ecosystems. Not only the carbon quantity, but also the average time that a carbon atom spends in dry matter before returning to the atmosphere determines the magnitude of any carbon sink (Galbraith et al., 2013).

The characteristics of PP used for fiber production could explain the difference in fallen necromass between the two ecosystems

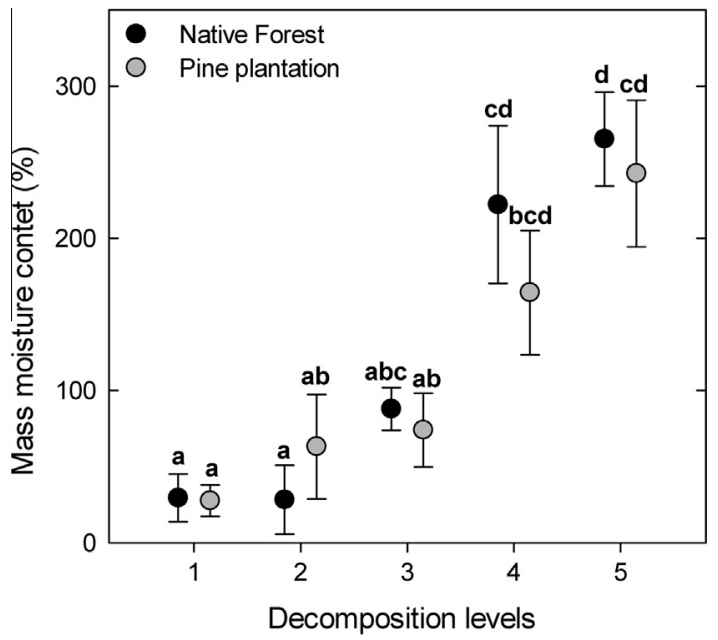

Fig. 4. Mass moisture content in CWD in NF and PP ecosystems for different decomposition levels (1-5). Different letters indicate significant differences between ecosystems and levels.

included in this study; PP were dominated by litter layer while NF debris had similar contributions of both types of debris (LL and CWD). These PP are even-aged and fast-growing ecosystems that do not include pruning or thinning (the dead branches remain on the trees). Moreover, they have a very early harvest age 
(10 years), and total residues are removed during harvest (Martiarena et al., 2011). Consequently, the input of CWD to the forest floor in PP appears to be low, and necromass does not accumulate from one cycle to the next one.

The necromass values found in this study are within the observed range for forest ecosystems (Woodall and Liknes, 2008). Nevertheless, detailed comparisons with previous studies are difficult because similar studies are infrequent, use a wide variety of methods and consider or classify the detritus pool differently. In the present study we followed the protocols established by Keller et al. (2004), Phillips and Baker (2002) and Palace et al. (2012), which do not consider standing dead trees in the aboveground necromass. However, several previous reports have considered this pool in the necromass quantification (Yan et al., 2007; Sefidi and Marvie Mohadjer, 2010; Iwashita et al., 2013). Consequently, we found lower necromass values than these studies. On the other hand, litter layer with a diameter under $2 \mathrm{~cm}$, as described in this survey, has been quantified in only a few studies (Martius et al., 2004; Woodall and Liknes, 2008; Zhou et al., 2014) and the values found here are higher than those previously described.

In forest ecosystems, the biomass in the litter layer stock is determined by changes in litter production (input) and litter decomposition (output) (Martius et al., 2004). In the PP, we observed a $180 \%$ increase in litter layer $\left(11.8 \mathrm{Mg} \mathrm{ha}^{-1}\right)$ compared with the NF $\left(6.6 \mathrm{Mg} \mathrm{ha}^{-1}\right)$. Preliminary data regarding litter production in the study sites indicates that litter input into the litter layer stock is similar in both ecosystems (Zaninovich S.C., unpublished data). On the other hand, the litter layer in PP is mainly composed of pine needles, which show a slow decomposition rate (Sanchez, 2001) when compared with the highly biodiverse litter ( $\sim 70$ tree species, Chediack, 2008) of NF. Consequently, the greater litter layer necromass of PP is associated with low rates of litter decay, which causes litter accumulation and generates a large quantity of dry matter aboveground (Arnaldos et al., 2004).

The CWD found in the present study is consistent with previous studies. The stock of fallen CWD $>2 \mathrm{~cm}$ varies widely between tropical and subtropical forests, ranging from 1.0 to $178.8 \mathrm{Mg} \mathrm{ha}^{-1}$ (Yan et al., 2007; Palace et al., 2012). In our NF sites, CWD ( $7.5 \mathrm{Mg} \mathrm{ha}^{-1}$ ) was less abundant than the CWD $(>2.5 \mathrm{~cm})$ in subtropical late-successional forests in China $\left(12.55 \mathrm{Mg} \mathrm{ha}^{-1}\right.$ in Tang et al., 2003; $84.45 \mathrm{Mg} \mathrm{ha}^{-1}$ in Liu et al., 1995). Transects much longer than were used in the present work have been recommended in order to capture the larger, but more infrequent diameter classes of CWD (Woldendorp et al., 2004; Iwashita et al., 2013). For this reason, our results may underestimate the biomass in the higher CWD size classes; until more information is available, comparisons of CWD $>10 \mathrm{~cm}$ should be made with caution. More CWD was observed in PP in the present study $\left(1.7 \mathrm{Mg} \mathrm{ha}^{-1}\right)$ than coarse necromass in coniferous early succession subtropical forests in China (0.09 $\mathrm{Mg} \mathrm{ha}^{-1}$ in Tang and Zhou, 2005). The quantity and distribution within CWD size classes in our NF study sites were similar to previous studies concerning low-disturbance late successional forests (Sefidi and Marvie Mohadjer, 2010). On the other hand, the distribution of CWD over decompositional levels that is described in the present study, in which the great majority of CWD is in levels 3, 4 and 5 (94\%) in the NF ecosystem, is consistent with other studies in temperate (Sefidi and Marvie Mohadjer, 2010) and subtropical forests (Yan et al., 2007). In the PP included in this study, decomposition level 1 (49\%) contained the largest proportion of CWD, a finding that is corroborated in a previous study of an early successional Pinus massoniana subtropical forest in China (Yan et al., 2007).

Our results concerning the total water volume retained in coarse necromass provide evidence of substantial water storage in this pool in NF ecosystems. Other studies have suggested that
CWD provides a large and relatively stable source of moisture when compared with litter layer or mineral soil (Fraver et al., 2002; Harmon and Sexton, 1995). Coarse woody debris necromass moisture content was not different between systems, though the quantity of CWD dry mass per unit area was greater in NF than in PP. Hence, the water volume retained in CWD was almost four times higher in NF. Debris in an advanced state of composition held more water than the less decayed debris, although no differences between systems were detected in our study. The greater waterholding capacity in more decomposed woody debris may be related to decreased wood density (Yu et al., 2004). The necromass moisture content values found in this study were lower than in other studies (Harmon and Sexton, 1995; Takahashi et al., 2000; Fraver et al., 2002) probably because measurements were taken during a period of low rainfall during an unusually dry winter. However, CWD water content fluctuates considerably over time and with changes in temperature, rainfall, and season (Fraver et al., 2002; Harmon and Sexton, 1995), so valid comparisons with other studies developed under different conditions or times are very difficult. Our results also support the idea that CWD not only has an important role as a $\mathrm{C}$ pool, but also plays an important role in the water absorption and storage in forests ecosystems (Harmon et al., 1986).

The water-holding capacity in the ecosystem imparts a remarkable resistance to drought and natural wildfires to closed-canopy rainforests (Bush et al., 2011). Even after months without rain, forests can maintain an evergreen canopy and high sub-canopy humidity levels, making sustained combustion very unlikely (Uhl and Kauffman, 1990). The CWD in NF systems that contained the highest water volume were principally composed of the largest coarse necromass, branches or stems of diameter $>10$, a finding that has been corroborated in other forests (Iwashita et al., 2013; Liu et al., 2006). This CWD size category was reduced in PP, explaining the low water volume found in this system. In addition, Pinus species belonging to the Pinus subgenus (including P. taeda) present characteristics associated with increased flammability: high retention of dead branches due to their non-self-pruning phenotype, thin terminal twigs, low needle density (which increases fuel surface area and influences ignition temperature and combustibility), and leaf litter consisting of resinous needles with a high terpene concentration (Schwilk and Ackerly, 2001; Ormeño et al., 2009). As a result, PP with high litter accumulation, low CWD and low water volume aboveground represent a more vulnerable, fire-prone system (Mutch, 1970; Agee, 1998; Schwilk and Ackerly, 2001) than NF. Wildfires are a significant direct and indirect source of global carbon emissions (Crutzen and Andrade, 1990; van der Werf et al., 2003). Therefore, the biomass stock contained in the total fallen necromass in PP under the current management in northern Argentina represents a more unstable pool compared to NF, even though these plantations show overall necromass values similar to those found in the NF ecosystems. This suggests that this PP is not an effective carbon storage strategy, as has been suggested for commercial tree plantations in general (Radtke et al., 2009).

Our study shows that commercial PP in subtropical ecosystems are an important issue that must be addressed with respect to necromass characteristics and dynamics. Recent efforts have addressed gap in our knowledge of how CWD contributes to forest carbon cycles and regional or global carbon budgets (Brown, 2002; Radtke et al., 2009). In Sweden, one of the most important measures adopted within the new, biodiversity-oriented forestry program is to increase the quantity of CWD in commercially managed forests. The strategies implemented include leaving existing dead trees in place, decreasing the destruction of CWD in the final cutting, and not removing naturally dying trees. All of these measures have had a strong positive influence on the amount 
of CWD (Ranius and Kindvall, 2004). On the other hand, the recovery of detritus after harvesting or natural disturbance can be quite slow, requiring as much as ca. 1000 years in some forests (Spies et al., 1988). Thus, understanding the role and natural dynamics of detritus in commercial PP and both managed and unmanaged forests is vital for the improvement of forest management strategies (Fraver et al., 2002).

Finally, but no less critically, the reduction in the volume of coarse necromass found in PP may have negative consequences for biodiversity. Coarse woody debris was an important source of habitat heterogeneity in NF (Fig. 3) and was nearly absent in PP. In addition, the water storage and sponge-like structure of welldecayed logs makes them an ideal habitat for moisture-sensitive species, like some amphibians and other organisms that directly depend on these structures for shelter (Petranka et al., 1994; Fraver et al., 2002; Yan et al., 2007). In this way, NF replacement and current management practices in commercial PP would likely lead to a decrease in the biodiversity of forest ecosystems. Management strategies that increase coarse necromass and biodiversity conservation should be considered in these PP. These strategies could include not removing harvest residues, to promote understory growth under non-native tree plantations (which could be stimulated by thinning) and to extend the tree harvest age. These practices would promote greater habitat heterogeneity, increasing tree mortality and CWD input to the PP floor, and would allow animal colonization of non-native tree plantations (Zurita and Bellocq, 2012).

\section{Conclusions}

Our study shows important changes in necromass stocks associated with changes in land use. Native forest replacement by 10 year-old non-native $P$. taeda plantations impacted fallen necromass, changing the equal distribution of CWD and LL in NF to a LL dominated (90\%) plantation floor. Although the total amount of necromass did not change between systems, the change in composition could have large effects on ecosystem functioning. These effects are related to, but not limited to, a shorter residence time of carbon in necromass, lower water storage in necromass, a higher risk of fires, and a potential decrease in biodiversity following NF replacement by young PP. Some management strategies in PP used for fiber production should be implemented in order to increase CWD in these productive systems, in which subsequent rotations would depend on the nutrient reservoirs above and below the forest floor. More, studies on necromass dynamics and the effects of different debris types on carbon and nutrient cycling, as well as storage under different land uses, are necessary.

\section{Acknowledgments}

This study was funded by the UCAR (Unidad para el Cambio Rural) and MAGyP (Ministerio de Agricultura, Ganadería y Pesca, Argentina) through PIA 10105, ANPCyT (Agencia Nacional de Promoción Científica y Tecnológica) through PICTO UNaM 0111 and CONICET (Consejo Nacional de Investigaciones Científicas y Técnicas, Argentina). We would like to thank Arauco Argentina S.A. for allowing the studies in its property; and Centro de Investigaciones del Bosque Atlántico (CeIBA) and Universidad Nacional del Nordeste for logistical support. We would also like to thank Gustavo A. Zurita as head of project PIA 10105, and Andrés Gómez Cifuentes, Victoria Giménez, Ana Múnevar, Yamil Di Blanco, Carolina Trentini, Débora Di Francescantonio, María del Rosario Montiel, Marta Duré, Félix Ignacio Contreras and Silvina Andrea Contreras for field and laboratory assistance.

\section{References}

Agee, J.K., 1998. Fire and pine ecosystems. In: Richardson, D.M. (Ed.), Ecology and Biogeography of Pinus. Cambridge University Press, Cambridge, pp. 193-218.

Arnaldos, J., Navalón, X., Pastor, E., Planas, E., Zárate, L., 2004. Manual de ingeniería básica para la prevención y extinción de incendios forestales. Ediciones MundiPrensa, Madrid, ES, pp. 414.

Bardgett, R., Wardle, D.A., 2010. Aboveground and belowground linkages. Biotic Interactions, Ecosystem Process, and Global Change. Oxford University Press, New York, USA.

Binkley, D., Fisher, R., 2013. Ecology and Management of Forest Soils, fourth ed. Wiley-Blackwell Inc., New York City, USA.

Brown, S., 2002. Measuring carbon in forests: current status and future challenges. Environ. Pollut. 116, 363-372.

Bush, M.B., Flenley, J.R., Gosling, W.D., 2011. Tropical Rainforest Responses to Climate Change, second ed. Springer/Praxis, Chichester, UK.

Chambers, J.Q., Higuchi, N., Schimel, J.P., Ferreira, L.V., Melack, J.M., 2000. Decomposition and carbon cycling of dead trees in tropical forests of the central Amazon. Oecologia 122, 380-388.

Chediack, S., 2008. Efecto de la explotación forestal sobre la estructura, diversidad y composición florística de los palmitales de la Selva Atlántica en Misiones, Argentina. Rev. Biol. Trop. 56 (2), 721-738.

Crutzen, P.J., Andrade, M.O., 1990. Biomass burning in the tropics - impact on atmospheric chemistry and biogeochemical cycles. Science 250, 1669-1678.

Eclesia, R.P., 2004. Consecuencias del reemplazo de ecosistemas naturales sudamericanos por forestaciones y pasturas megatérmicas: efectos sobre el carbono orgánico edáfico. (Magister's thesis-Universidad de Buenos Aires, Argentina), pp. 100

Eclesia, R.P., Jobbagy, E.G., Jackson, R.B., Biganzoli, F., Piñeiro, G., 2012. Shifts in soil organic carbon for plantation and pasture establishment in native forests and grasslands of South America. Global Change Biol. 18, 3237-3251.

Franklin, J.F., Shugart, H.H., Harmon, M.E., 1987. Tree death as an ecological process. Bioscience 37, 550-556.

Fraver, S., Wagner, R.G., Day, M., 2002. Dynamics of coarse woody debris following gap harvesting in the Acadian forest of central Maine, U.S.A. Can. J. For. Res. 32, 2094-2105.

Galbraith, D., Malhi, Y., Affum-Baffoe, K., Castanho, A.D.A., Doughty, C.E., Fisher, R.A., Lewis, S.L., Peh, K.S.H., Phillips, O.L., Quesada, C.A., 2013. Residence times of woody biomass in tropical forests. Plant Ecol. Div. 6, 139-157.

Gatti, M.G., Campanello, P.I., Montti, L.F., Goldstein, G., 2008. Frost resistance in the tropical palm Euterpe edulis and its pattern of distribution in the Atlantic Forest of Argentina. For. Ecol. Manage. 256, 633-640.

Goya, J.F., Pérez, C., Frangi, J.L., Fernández, R., 2003. Impacto de la cosecha y destino de los residuos sobre la estabilidad del capital de nutrientes en plantaciones de Pinus taeda L. Ecol. Austral 13, 139-150.

Grace, J., Lloyd, J., McIntyre, J., Miranda, A.C., Meir, P., Miranda, H.S., Nobre, C., Moncrieff, J., Massheder, J., Malhi, Y., Wright, I., Gash, J., 1995. Carbon dioxide uptake by an undisturbed tropical rain forest in southwest Amazonia, 19921993. Science 270, 778-780.

Guo, L.B., Gifford, M., 2002. Soil carbon stocks and land use change: a meta analysis. Global Change Biol. 8, 345-360.

Harmon, M.E., Franklin, J.F., Swanson, F.J., Sollins, P., Gregory, S.V., Lattin, J.D., Anderson, N.H., Cline, S.P., Aumen, N.G., Sedell, J.R., Lienkaemper, G.W., Cromack, K., Cummins, K.W., 1986. Ecology of coarse woody debris in temperate ecosystems. Adv. Ecol. Res. 15, 133-302.

Harmon, M.E., Sexton, J., 1995. Water balance of conifer logs in early stages of decomposition. Plant Soil 172, 141-152.

Hoen, H.F., Solberg, B., 1994. Potential and economic efficiency of carbon sequestration in forest biomass through silvicultural management. For. Sci. 40, 429-451.

Iwashita, D.K., Litton, M.C., Giardina, C.P., 2013. Coarse woody debris carbon storage across a mean annual temperature gradient in tropical montane wet forest. For. Ecol. Manage. 291, 336-343.

Izquierdo, A.E., De Angelo, C.D., Aide, T.M., 2008. Thirty years of human demography and land use change in the Atlantic forest of Misiones, Argentina: an evaluation of the forest transition model. Ecol. Soc. 13, 3.

Keller, M., Palace, M., Asner, G.P., Pereira Jr., R., Silva, J.N.M., 2004. Coarse woody debris in undisturbed and logged forests in the eastern Brazilian Amazon. Global Change Biol. 10, 784-795.

Krankina, O.N., Harmon, M.E., 1995. Dynamics of the dead wood carbon pool in northwestern Russian boreal forests. Water Air Soil Pollut. 82, 227-238.

Ligier, H.D., Matteio, H.R., Polo, H.L., Rosso, J.R., 1990. Provincia de Misiones. In: Atlas de suelos de la República Argentina, Tomo II. Centro de Investigaciones de Recursos Naturales, INTA, Secretaria de Agricultura, Ganadería y Pesca. Buenos Aires, Argentina, pp. 111-154.

Lindenmayer, D.B., Noss, R.E., 2006. Salvage logging, ecosystem processes, and biodiversity conservation. Conserv. Biol. 20, 949-958.

Liu, W.Y., Xie, S.C., Xie, K.J., Yang, G.J., 1995. Preliminary studies on the litterfall and coarse woody debris in mid-mountain humid evergreen broadleaved forest in Ainao mountains. Acta Bota. Sin. 37, 807-814 (in Chinese, with English abstract).

Liu, W.H., Bryant, D.M., Hutyra, L.R., Saleska, S.R., Hammond-Pyle, E., Curran, D., Wofsy, S.C., 2006. Woody debris contribution to the carbon budget of selectively logged and maturing mid-latitude forests. Oecologia 148, 108-117. 
MAGyP (Ministerio de Agricultura, Ganadería y Pesca, Argentina), 2015. Sistema de información geográfica. Inventario Forestal. <http://www.minagri.gob.ar/new/ $0-0 /$ forestacion/inventario/mapa\%20de\%20planta.html> (last consultation: June 2015).

Malhi, Y., Nobre, A.D., Grace, J., Kruijt, B., Pereira, M.G.P., Culf, A., Scott, S., 1998. Carbon dioxide transfer over a central Amazonian rain forest. J. Geophys. Res. Atmos. 103, 31593-31612.

Martiarena, R.A., 2008. Cuantificación y evaluación del contenido de fósforo exportado en plantaciones de Pinus taeda conducido con diferentes intensidades de raleo y alternativos sistemas de cosecha. (Master's thesisUniversidad Nacional de Misiones, Argentina), pp. 223.

Martiarena, R.F., Frangi, J.L., Pinazo, M.A., Von Wallis, A., Fernández, R.A., 2011. Effect of Thinning and Harvest Type on Storage and Losses of Phosphorous in Pinus taeda L. Plantations in Subtropical Argentina. Int. J. For. Res. Article ID 761532, 10 pages http://dx.doi.org/10.1155/2011/761532 http://www. hindawi.com/journals/ijfr/2011/761532/ (last consultation: June 2015).

Martius, C., Höfer, H., Garcia, M.V.B., Römbke, J., Hanagarth, W., 2004. Litter fall, litter stock and decomposition rates in rainforest and agroforestry sites in central Amazonia. Nutr. Cycl. Agroecosys. 68, 137-154.

Melillo, J.M., McGuire, A.D., Kicklighter, D.W., Moore, B., Vorosmarty, C.J., Schloss, A. L., 1993. Global climate change and terrestrial net primary productivity. Nature 363, 234-240.

MODIS, 2014. Land Subsets. Oak Ridge National Laboratory DAAC. <http://daac. ornl.gov/cgi-bin/MODIS/GLBVIZ_1_Glb/modis_subset_order_global_col5.pl> (last consultation: December 2014).

Montti, L., Campanello, P.I., Gatti, M.G., Blundo, C., Austin, A., Sala, O.E., Goldstein, G., 2011. Undestory bamboo flowering provides a very narrow light window of opportunity for canopy-tree recruitment in a neotropical forest of Misiones, Argentina. For. Ecol. Manage. 262, 1360-1369. http://dx.doi.org/10.1016/ j.foreco.2011.06.029.

Mutch, R.W., 1970. Wildland fires and ecosystems - a hypothesis. Ecology 51 (6), 1046-1052.

Ormeño, E., Céspedes, B., Sánchez, I.A., Velasco-García, A., Moreno, J.M., Fernandez, C., Baldy, V., 2009. The relationship between terpenes and flammability of leaf litter. For. Ecol. Manage. 257, 471-482.

Palace, M., Keller, M., Asner, G.P., Silva, J.N.M., Passos, C., 2007. Necromass in undisturbed and logged forerst in Brazilian Amazon. For. Ecol. Manage. 238, 309-318.

Palace, M., Keller, M., Silva, H., 2008. Necromass production: studies in undisturbed and logged Amazon forests. Ecol. Appl. 18, 873-884.

Palace, M., Keller, M., Hurtt, G., Frolking, S., 2012. A Review of Above Ground Necromass in Tropical Forests, Tropical Forests, Dr. Padmini Sudarshana (Ed.), ISBN: 978-953-51-0255-7, In Tech, DOI: 10.5772/33085. <http://www. intechopen.com/books/tropical-forests/a-review-of-above-ground-necromassin-tropical-forests> (last consultation: June 2015).

Parodi, R.L., 1964. Capítulo I: Las regiones fitogeográficas argentinas. In: Enciclopedia Argentina de agricultura y jardinería. Volumen II, El cultivo de las plantas útiles. Primera parte, capítulos I al XXI. ACME (Ed.), Buenos Aires, Argentina, pp. 1-14.

Petranka, J.W., Brannon, M.P., Hopey, M.E., Smith, C.K., 1994. Effects of timber harvesting on low elevation populations of southern Appalachian salamanders. For. Ecol. Manage. 67, 135-147.

Phillips, O.L., Malhi, Y., Higuchi, N., Laurance, W.F., Núñez, P.V., Vásquez, R.M., Laurance, S.G., Ferreira, L.V., Stern, M., Brown, S., Grace, J., 1998. Changes in the carbon balance of tropical forests: evidence from long-term plots. Science 282, 439-442.

Phillips, O., Baker, T., 2002. Field manual for plot establishment and remeasurement (RAINFOR). Pan-Amazonia: Project for de advancement of networked science in Amazonia. <http://www.geog.leeds.ac.uk/projects/rainfor/manuals/plot_ establishment_and_remeasurement_english.pdf> (last consultation: June 2015).

Phillips, O.L., Aragão, L.E.O., Lewis, S.L., Fisher, J.B., Lloyd, J., López-González, G., Malhi, Y., Monteagudo, A., Peacock, J., Quesada, C.A., Van der Heijden, G., Almeida, S., Amaral, I., Arroyo, L., Aymard, G., Baker, T.R., Bánki, O., Blanc, L., Bonal, D., Brando, P., Chave, J., Alves de Oliveira, A.C., Dávila Cardozo, N., Czimczik, C.I., Feldpausch, T.R., Freitas, M.A., Gloor, E., Higuchi, N., Jiménez, E., Lloyd, G., Meir, P., Mendoza, C., Morel, A., Neill, D.A., Nepstad, D., Patiño, S., Peñuela, M.C., Prieto, A., Ramírez, F., Schwarz, M., Silva, J., Silveira, M., Sota Thomas, A., Ter Steege, H., Stropp, J., Vásquez, R., Zelazowski, P., Alvarez Dávila, E., Andelman, S., Andrade, A., Chao, K., Erwin, T., Di Fiore, A., Honorio, E., Keeling, H., Killeen, T.J., Laurance, W.F., Peña Cruz, A., Pitman, N.C.A., Núñez Vargas, P., Ramírez-Angulo, H., Rudas, A., Salamão, R., Silva, N., Terborgh, J., Torres-Lezama, A., 2009. Drought sensitivity of the Amazon rainforest. Science 323, 1344.

Potter, C.S., Randerson, J.T., Field, C.B., Matson, P.A., Vitousek, P.M., Mooney, H.A., Klooster, S.A., 1993. Terrestrial ecosystem production: a process model based on global satellite and surface data. Global Biogeochem. Cycles 7, 811-841.

Prado, D.E., Gibbs, P.E., 1993. Patterns of species distributions in the dry seasonal forests of South America. Ann. Mo. Bot. Gard. 80, 902-927.

Pütz, S., Groeneveld, J., Henle, K., Knogge, C., Camargo Martensen, A., Metz, M., Metzger, J.P., Ribeiro, M.C., Dantas de Paula, M., Huth, A., 2014. Long-term carbon loss in fragmented Neotropical forests. Nat. Commun. 5, 5037. http://dx. doi.org/10.1038/ncomms6037.
Radtke, P.J., Amateis, R.L., Prisley, S.P., Copenheaver, C.A., Chojnacky, D.C., Pittman, J. R., Burkhart, H.E., 2009. Modeling production and decay of coarse woody debris in loblolly pine plantations. For. Ecol. Manage. 257, 790-799.

Ranius, T., Kindvall, O., 2004. Modelling the amount of coarse woody debris produced by the new biodiversity-oriented silvicultural practices in Sweden. Biol. Conserv. 119, 51-59.

Ribeiro, M.C., Metzger, J.P., Camargo Martensen, A., Ponzoni, F.J., Hirota, M.M., 2009 The Brazilian Atlantic Forest: How much is left, and how is the remaining forest distributed? Implications for conservation. Biol. Conserv. 142, 1141-1153.

Rice, A.H., Pyle, E.H., Saleska, S.R., Hutyra, L., Palace, M., Keller, M., De Camargo, P.B., Portilho, K., Marques, D.F., Wofsy, S.C., 2004. Carbon balance and vegetation dynamics in an old-growth Amazonian forest. Ecol. Appl. 14, 55-71.

Sanchez, F.G., 2001. Loblolly pine needle decomposition and nutrient dynamics as affected by irrigation, fertilization, and substrate quality. For. Ecol. Manage. 152 X5-X96.

Schwilk, D., Ackerly, D.D., 2001. Flammability and serotiny as strategies: correlated evolution in pines. Oikos 94, 326-336.

Sefidi, K., Marvie Mohadjer, M.R., 2010. Characteristics of coarse woody debris in successional stages of natural beech (Fagus orientalis) forests of Northern Iran. J. For. Sci. 56 (1), 7-17.

Simberloff, D., Nuñea, M.A., Ledgard, N.J., Pauchard, A., Richardson, D.M., Sarasola M., Van Wilgen, B.W., Zalba, S.M., Zenni, R.D., Bustamante, R., Peña, E., Ziller, S. R., 2010. Stread and impact of introduced conifers in South America: lessons from other southern hemisphere regions. Austral Ecol. 35, 489-504.

Spies, T.A., Franklin, J.F., Thomas, T.B., 1988. Coarse woody debris in Douglas-fir forests of western Oregon and Washington. Ecology 69, 1689-1702.

Srur, M., Gatti, F., Benesovsky, V., Herrera, J., Melzew, R., Camposano, M., 2009. Los tipos de vegetación y ambientes del Parque Nacional Iguazú y su distribución en el paisaje. In: Parque Nacional Iguazú, Conservación y desarrollo en la Selva Paranaense de Argentina, editado por Bruno Carpinetti, Mirta Garciarena y Marcelo Almirón, - $1^{\text {a }}$ ed. -Buenos Aires: Administración de Parques Nacionales, pp. 99-118.

Stevens, V., 1997. The ecological role of coarse woody debris, an overview of the ecological importance of CWD in BC forests. Working paper ministry of forest research program, British Columbia, pp. 30-97.

Takahashi, M., Sakai, Y., Ootomo, R., Shiozaki, M., 2000. Establishment of tree seedlings and water-soluble nutrients in coarse woody debris in an old-growth Picea-Abies forest in Hokkaido, northern Japan. Can. J. For. Res. 30, 1148-1155.

Tang, X.L., Zhou, G.Y., Zhou, X., Wen, D.Z., Zhang, Q.M., Yin, G.C., 2003. Coarse woody debris in monsoon Evergreen broad-leaved forests of Jinhushan nature reserve. Acta Phytoecol. Sin. 27, 484-489 (in Chinese, with English abstract).

Tang, X.L., Zhou, G.Y., 2005. Coarse woody debris biomass and its potential contribution to the carbon cycle in successional subtropical forests of Southern China. Acta Phytoecol. Sin. 29 (4), 559-568 (in Chinese, with English abstract).

Tiarks, A., Nambiar, E., Cossalter, C., 1998. Site management and productivity in tropical forest plantations. Center for International Forestry Research (CIFOR) Occasional paper $\mathrm{N}^{\circ} 16$

TRMM Online Visualization and Analysis System (TOVAS). NASA, 2014. <http:// gdata1.sci.gsfc.nasa.gov/daac-bin/G3/gui.cgi?instance_id=TRMM_3-Hourly> (last consultation: December 2014)

Uhl, C., Kauffman, J.B., 1990. Deforestation, fire susceptibility, and potential tree responses to fire in the eastern Amazon. Ecology 7, 437-449.

UNFCCC, 1992. United Nations Framework Convention on Climate Change. A/ AC.237/18 (Part II)/Add.1. United Nations, New York, p. 29.

USDA, 2004. National Report on Sustainable Forests - 2003. U.S. Department of Agriculture, Forest Service. FS-766. Washington, D.C.

Van der Werf, G.R., Randersong, J.T., Collatz, G.J., Giglio, L., 2003. Carbon emissions from fires in tropical and subtropical ecosystems. Global Change Biol. 9, 547562.

Weedon, J.T., Cornwell, W.K., Cornelissen, J.H.C., Zanne, A.E., Wirth, C., Coomes, D.A. 2009. Global meta-analysis of wood decomposition rates: a role for trait variation among tree species? Ecol. Lett. 12, 45-56.

Woodall, C.W., Liknes, G.C., 2008. Relationships between forest fine and coarse woody debris carbon stocks across latitudinal gradients in the United States as an indicator of climate change effects. Ecol. Indic. 8, 686-690.

Woldendorp, G., Keenan, R.J., Barry, S., Spencer, R.D., 2004. Analysis of sampling methods for coarse woody debris. For. Ecol. Manage. 198, 133-148.

Yan, E.R., Wang, X.H., Huang, J.J., Zeng, F.R., Gong, L., 2007. Long-lasting legacy of forest succession and forest management: characteristics of coarse woody debris in an evergreen broad-leaved forest of Eastern China. For. Ecol. Manage. 252, 98-107.

Yu, X., Chen, L., Niu, J., Yutao, Z., 2004. Hydrological effects of CWD in sub-alpine dark coniferous ecosystem of upper reaches of Yangtze River. Sci. Soil Water Conserv. 2, 117-122.

Zar, J., 1999. Biostatistical Analysis, fourth ed. Prentice Hall, USA, 663.

Zhou, Y., Su, J., Janssens, I.A., Zhou, G., Xiao, C., 2014. Fine root and litterfall dynamics of three Korean pine (Pinus koraiensis) forests along an altitudinal gradient. Plant Soil 374, 19-32.

Zurita, G.A., Bellocq, M.I., 2012. Bird assemblages in anthropogenic habitats: identifying a suitability gradient for native species in the Atlantic forest. Biotropica 44, 412-419. 